\title{
Preface
}

\section{Press freedom in Asia: an uneven terrain}

\section{Amando Doronila}

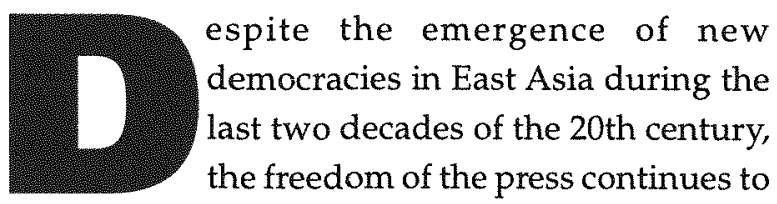

be under siege in the region. During those decades, the democratic wave in East Asia swept out authoritarian regimes in the Philippines (1986), Thailand (1992), South Korea (1992), and Indonesia (1998), making way for more pluralistic and open politics in those countries. Also in the 1980s, Taiwan abandoned authoritarian rule, and the press in that country is rated by the New York-based Committee to Protect Journalists as one of the freest in the region.

The emergence of an outspoken and assertive press is an indicator of political democratisation. But a free press is neither a gift from heaven nor of the democratic process. Often, a free press precedes the fall of authoritarian regimes. Indeed, it is a harbinger of political change towards more open politics. The press plays a frontline role in political change, but it has to continue to struggle to preserve its gains, even after the election of a democratic government.

In Asia, one cannot talk about democracy or freedom of the press without qualifications. While democracy and freedom of the press are inseparable notions, one cannot assume these twin notions take the same focus in Asia as in North American and Western European democracies. A survey of the state of the press of the region must take into account the diversity of political cultures in the region and the specific ways that Asian governments are tolerant towards a critical or adversarial press.

In Asia, it is a valid proposition that freedom of the press, even in new and restored democracies (like the Philippines), is measured in terms of degrees in which frankness and criticism are tolerated by governments 
and their societies. Thus, while the press in the Philippines is probably the most unfettered in the region and replicates the western models of a free press, the Philippine press is not necessarily the role model for the rest of East Asia. The Philippines is East Asia's oldest constitutional democracy and has copied American-style presidential democracy, much to the dismay of Singapore's Senior Minister Lee Kuan Yew, who considers the Filipino adversarial press and politics a source of political impasse that hampers economic development.

Filipino democracy is not the same as Thai, Korean, or Indonesian democracy, although all have adopted the minimalist criteria of having free elections and varying degrees of press freedom.

And so, as we scan the East Asian political landscape in the midst of the emergence of new democracies at the end of the century, and in the aftermath of the economic crises that shattered the bubble of the Asian tigers' economic miracles of the 1980s, we see an uneven, even treacherous, terrain of press freedom. I think the best metaphor to describe the political environment for press freedom in Asia today is that it is a minefield in which the press and journalists must tread carefully. They must be sensitive to such things as 'Asian values'-often a rationalisation for autocratic rule or political repression, or a justification of corruption.

While the press is outspoken in the new democracies, journalists and newspapers face constraints on their freedom in much of the rest of East Asia. In Singapore and Malaysia, for example, draconian Official Secrets Acts and national security legislation, as well as legal action from governments, restrict publication of news that governments would consider inimical to 'national security' or 'national interests'. Newspapers in those countries are government controlled. Coincidentally, these two countries which, before the outbreak of the East Asian financial crisis in mid 1997, had been brilliant performers economically, were also the main sources of the doctrine of 'Asian values', in defence of restrictive political environments (parliamentary systems of the Westminster mould).

Foreign correspondents face risks of expulsion in a number of Southeast Asian countries if they write news that displeases regimes. And in Northeast Asia, after the handover of Hong Kong to China, the cloud of uncertainty hangs heavily over the freedom of the press.

Only after the fall of the Soeharto regime was the system of licensing newspapers lifted, liberating latent restlessness of Indonesian journalists 
over the state of affairs under 32 years of authoritarian rule, and opening an era of a critical press. The Soeharto regime had been described by the Committee to Protect Journalists as a perennial among its annual ' 10 worst enemies'. Its collapse triggered a wave of political reforms, including widening the freedom of the press.

Myanmar stands out as the worst case of political repression in Southeast Asia, and the press in Indochina suffers from the state-imposed restrictions of a socialist system, albeit trying to find its way into the market economy.

Against this uneven terrain, there are some hopeful developments for press freedom. In the environment of political liberalisation in Southeast Asia, journalists in the Philippines, a restored democracy, and the new democracies of Thailand and Indonesia have moved to consolidate and protect the freedoms they have gained. In 1998, the press organisations from these three countries organised the Southeast Asian Press Alliance (SEAPA), devoted to promoting and protecting press freedom.

The different paths towards political openness and the varying levels of tolerance for press freedom in East Asia have raised challenges to certain notions about democratic liberalisation or political change, and its relationship to economic development.

The restoration of democracy in the 1986 People Power Revolution in the Philippines does not substantiate the theory that political liberalisation is a consequence of economic prosperity. The revolution exploded from deep national distress fostered by political and social unrest against a corrupt and repressive Marcos regime. The economy had plunged into negative growth, and the Filipino middle class, that had broadened its base in the earlier years of economic growth, was the moving force behind the revolution. It had lost its gains, and revolted against pauperisation.

Prior to the East Asian financial crisis, there had been a fanciful perspective, supported by some Australian academics, that economic development had created a docile middle class which did not want to rock the boat lest they lose their economic gains. In this perspective, the middle class is deemed to have made a Faustian pact in which it trades off political activism in exchange for economic benefits. Singapore and Malaysia are cited as examples.

But the Indonesian unrest leading to the resignation of President Soeharto in May 1998 turned this perspective on its head. Two decades of high economic growth fostered by an authoritarian regime that brooked 
no criticism from the press or politicians did not prevent the development of political movements originating from the streets and the distressed countryside to demand the resignation of Soeharto.

The economic collapse in Indonesia stemming from the crisis forced to the surface the effects of the lethal combination of corruption and the economic slowdown, hitting both the Indonesian middle and lower classes.

One of the important consequences of the East Asian financial crisis is that it accented the lack of transparency of financial systems in the region. While the crisis devastated all economies of the region, countries which were hit harder were also those that were least transparent about their financial transactions. These were countries where freedom of the press and access to information were restricted.

Post-crisis assessments in international conferences surveying what went wrong with the Asian miracle now underline the importance of transparency as a condition for recovery and avoidance of another severe economic crisis. By implication, the free press is essential for transparency. This post-crisis assessment not only provides reinforcement for a free press in developing societies rebounding from the crisis but also deflates the notion that a free press is a western value, not suited to culturally and politically diverse Asia.

On an anecdotal basis, I have always been uncomfortable with the notion that press freedom is alien to 'Asian values'. During decades of travelling to cover crises in Asia and even in Eastern Europe behind the Iron Curtain, I have had candid talks with journalists and editors in these regions. Over drinks and good food, journalists in countries with a captive press talk freely about what they know but cannot write because regimes don't allow it. Journalists everywhere have a universal bond-they are all the same. They talk freely among themselves. They know a lot, but they also know what not to disclose and are keenly aware of what is possible.

So, when conditions permit, they break loose from their shackles, they write what they know and they plunge into the struggle for open politics and press freedom. Press freedom is a language journalists know by instinct. It is not a western construct. Thus, when the Soviet system broke down, Pravda overnight blossomed into a free newspaper in which journalists who dared to write the unprintable were no less rambunctious than their western counterparts. 
Indonesian editors I had met just before the fall of Soeharto were critical of the regime when talking to fellow journalists. However they said they could not write what they knew. But as soon as the windows opened to the new wind of change, journalists jumped into the stream of press freedom like fish swimming in water.

What bothers me is that new ways of stifling the press have found their way into new democracies and even in a restored democracy like the Philippines.

The press is used to conventional modes of suppression-libel cases, withdrawal of licences, expulsion of foreign correspondents, jailing, assassinations, censorship or self-censorship, and outright violence (as experienced by those covering ethnic riots).

With the advent of democratisation, there are fewer blatant reprisals such as raids by soldiers or jailing of recalcitrant and independent-minded journalists. More subtle methods have found their way into East Asia from Latin America where, despite the democratic wave, old habits of press suppression die hard, even at the hands of democratically elected governments.

The new method is economic strangulation of the press through withdrawal of advertising at the instigation of governments retaliating against press criticism. This new and insidious method, introduced by the democratically elected government of President Joseph Estrada, has hit the independent newspaper, Philippine Daily Inquirer, the country's largest English daily. This method uses ostensibly democratic and legal means to strangle press freedom and undermine democracy.

The introduction of new weapons to muzzle a free press warns against complacency. The fact that East Asia is moving-albeit slowly-towards more plural and participatory politics does not ensure that freedom of the press is protected. The press owes it to itself to continue to fight to preserve and expand its gains.

I very much welcome the initiative to survey the state of the media in Asia in this book, Losing Control: freedom of the press in Asia, and I commend the Centre for Democratic Institutions at the Australian National University for seeing the project through to fruition. One of the strengths of the book is that it has been written largely by working journalists. It is important, every now and then, to look critically at one's own profession and industry and to compare it to best-practice ideals. Constructive 
criticism, especially that coming from local journalists themselves, can greatly assist the cause of achieving freedom of expression throughout Asia.

The editors, Louise Williams and Roland Rich, have considerable firsthand experience in the region and shared with me and other Filipino journalists the exhilaration of the first years of freedom following the fall of the Marcos regime while they were both posted in Manila. I am delighted to be working with them again.

Amando Doronila

11 November 1999, Manila 